\title{
DIE REG OP REGSVERTEENWOORDIGING TYDENS ADMINISTRATIEWE VERRIGTINGE
}

\author{
MC Roos ${ }^{1}$ \\ Noordwes-Universiteit (Potchefstroom Kampus)
}

\section{$1 \quad$ Inleiding}

Die vraag of ' $n$ betrokkene mag aandring op regsverteenwoordiging tydens administratiewe verrigtinge, kom normaalweg aan die orde tydens dissiplinêre verhore, maar is uiteraard ook relevant by ander tipes administratiewe verrigtinge. Reeds voor die huidige grondwetlike bedeling is die vraag gereeld geoppper of daar nie in sekere omstandighede sprake is van 'n reg op regsverteenwoordiging voor administratiewe tribunale nie.

Voor aanvaarding van die huidige Grondwet ${ }^{2}$ en die Promotion of Administrative Justice Act, ${ }^{3}$ is geen absolute reg op regsverteenwoordiging erken tydens enige verrigtinge buite 'n geregshof nie. Die dictum in Dabner $v$ SAR \& $H^{4}$ is herhaaldelik aangehaal, naamlik:

[n]o roman-Dutch authority was quoted as establishing the right of legal representation before tribunals other than courts of law, and I know of none

'n Reg op regsverteenwoordiging sou slegs vestig indien dit uitdruklik of by noodwendige implikasie statutêr verleen is. ${ }^{5}$ Die reg op regsverteenwoordiging kon statutêr uitgesluit word, soos die geval was in Dabner. Die grys area waar regsverteenwoordiging nie uitdruklik of by implikasie gemagtig of verbied is nie, het gelei tot akademiese debat en 'n veeltal uitsprake, wat kortliks ontleed sal word.

Die vraag wat ontstaan en aangespreek word is of die Grondwet, die Wet en die Hoogste Hof van Appèl se onlangse uitspraak in Hamata and Another v Chairperson, Peninsula Technikon Internal Disciplinary Committee ${ }^{6}$ die onsekerheid en vraagstukke omtrent die kwessie te ruste lê. Die regsposisie met betrekking tot huishoudelike tribunale word ook oorweeg.

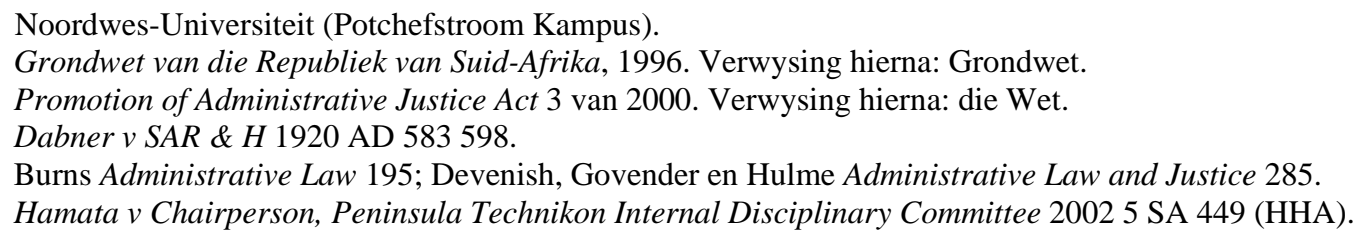




\section{Gemeenregtelike posisie}

Outeurs is dit eens dat regsverteenwoordiging nie 'n kernvereiste was vir nakoming van die audi alteram partem-reël nie. ${ }^{7}$

Rose Innes meen dat die reg op regsverteenwoordiging afhang van die aard van die administratiewe optrede. Indien die handeling regsprekend van aard is, sal 'n reg op regsverteenwoordiging bestaan. Indien dit kwasi-judisieel is, is dit nie 'n basiese vereiste vir geldige administratiewe optrede indien 'n statuut swyg daaromtrent nie. Regsverteenwoordiging mag geldig ontsê word en 'n persoon geniet slegs sodanige reg indien daar 'n statutêre basis daarvoor bestaan. ${ }^{8}$ Hy noem wel dat daar 'n reg op regsverteenwoordiging afgelei kan word uit wetgewing wat statutêre lisensiëringsliggame, soos byvoorbeeld 'n Drankraad, daarstel. ${ }^{9}$ 'n Tribunaal mag wel regsverteenwoordiging toelaat, maar hy beklemtoon dat daar geen sodanige plig op 'n liggaam rus nie. ${ }^{10}$

Baxter se opsomming van die gemeenregtelike posisie is dat regsverteenwoordiging nie essensieel is wanneer 'n verhoor wel toegestaan word nie. Slegs in buitengewoon gekompliseerde gevalle, waar die getuienis of regsbeginsels gekompliseerd is, mag regsverteenwoordiging as 'n sine qua non vir 'n billike verhoor geag word. Hy is van mening dat die buigsaamheid van die reëls van natuurlike geregtigheid hiervoor voorsiening mag maak. ${ }^{11}$

Wiechers onderskei die regsposisie van amptenare wat dissiplinêr verhoor word, van ander administratiewe handelinge, byvoorbeeld aansoeke vir lisensies. By laasgenoemde behoort die element van vrywillige aanvaarding van die regsreëls wat die aansoek-prosedure beheers, insluitend 'n moontlike statutêre uitsluiting van die reg op regsverteenwoordiging, deurslaggewend te wees. Aan die ander kant behoort 'n reg op regsverteenwoordiging erken te word tydens dissiplinêre verhore van staatsamptenare, tensy dit statutêr uitgesluit is. Hy betwyfel die wenslikheid van die uitspraak in Dabner omdat hy van mening is dat ernstige gevolge en die feit dat die amptenaar "teen wil en dank met 'n aanklag gekonfronteer" word, 'n situasie is waar die howe "uiters onwillig [behoort] te wees om die reg op regsverteenwoordiging te negeer". ${ }^{12}$

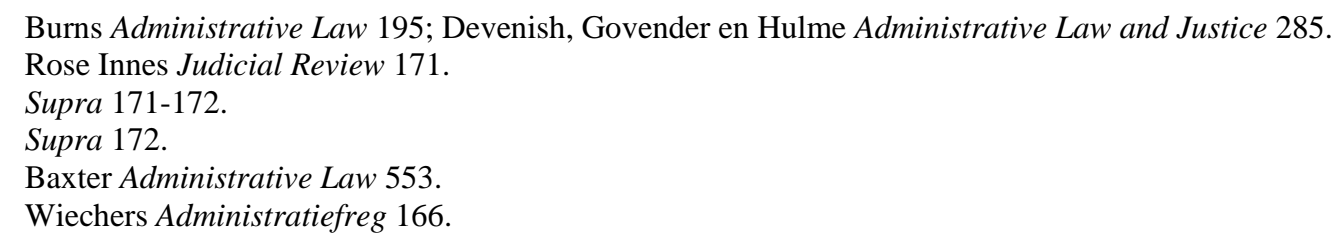


In ander gevalle is regsverteenwoordiging nie 'n wesenlike vereiste vir nakoming van die audi alteram partem-reël se aanhoringskomponent nie. ${ }^{13}$

Wiechers is van mening dat die vraag of regverteenwoordiging toegelaat word, beantwoord behoort te word met verwysing na die erns en kompleksiteit van die betrokke aangeleentheid en die erns en impak van moontlike gevolge. Op grond van billikheid en regverdigheid mag regsverteenwoordiging dan selfs 'n komponent van nakoming van die aanhoringsvereiste wees - die aard van verrigtinge en moontlike impak daarvan op die onderdaan sal bepaal of die aanhoringsvereiste nagekom is en nie die formele toets of regsverteenwoordiging veroorloof is deur wetgewing nie. ${ }^{14}$ Die outeur waarsku teen 'n onderskatting van die aard van die reëls van natuurlike geregtigheid, wat sal meebring dat 'n formele benadering verkies word in plaas daarvan om behoorlik oorweging te skenk aan die meriete van elke geval. ${ }^{15}$

Die howe se benadering tot die angeleentheid het egter nie Wiechers se uiteensetting weerspieel nie. Dit is nie altyd duidelik of daar bevind is dat die outeur van 'n beoogde administratiewe handeling 'n diskresie gehad het om toelating van regverteenwoordiging te oorweeg al dan nie.

In Smith v Beleggende Outoriteit van Kommandement Noord-Transvaal van die SA Weermag ${ }^{16}$ word Wiechers se uiteensetting in 'n vroeëre uitgawe van sy werk aangehaal, maar die hof is van mening dat die dissiplinêre aanklag teen die applikant en moontlike sanksie by skuldigbevinding nie so ernstig is dat weiering van regsverteenwoordiging die audi-reël sal skend nie. ${ }^{17}$ Daar word gesteun op die Engelse beslissing Fraser v Mudge, ${ }^{18}$ waarin opgemerk is dat dit in die weermag en vloot gevestigde praktyk is om nie regsverteenwoordiging toe te laat tydens dissiplinêre aangeleenthede nie, om afhandeling te bespoedig. ${ }^{19}$ Deur die statutêre posisie van 'n verhoor in casu te vergelyk met 'n verhoor voor 'n krygsraad waar regsverteenwoordiging wel toegelaat word, bevind die hof op grond van die stelreël inclusio unius est exclusio alterius, dat "geen regsverteenwoordiging by verrigtinge voor 'n verhooroffisier beoog word nie". ${ }^{20}$ Omdat 'n reg op regsverteenwoordiging nie uit die toepaslike statutêre bepalings

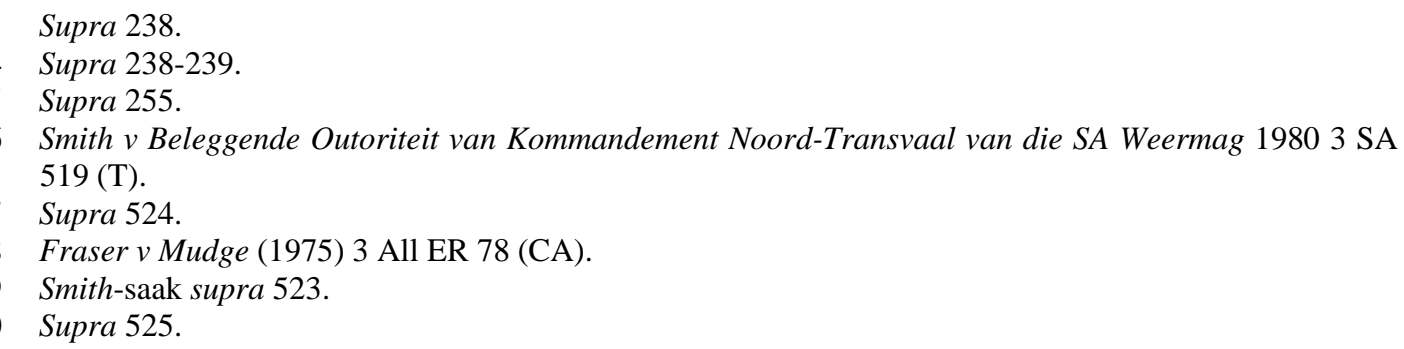


afgelei kan word nie, beslis die hof dat die applikant "geen basis kan aantoon vir sodanige reg in die huidige geval nie" en wys die aansoek van die hand. ${ }^{21}$

Die hof gaan egter verder en hoewel dit nie uitdruklik bevind dat die verhoorliggaam 'n diskresie het wat behoorlik uitgeoefen moet word nie, word daar wel (obiter) opgemerk dat dit nie onwettig of onreëlmatig sou wees om regsverteenwoordiging toe te laat nie en dat dit die respondent vrystaan om dit wel toe te laat. Die hof wys op die ingewikkelde regsbeginsels (die klag het gehandel oor dishonorering van 'n tjek) wat afgeweeg kan word teenoor doelmatigheidsoorwegings en die feit dat die verhoorliggaam nooit die toelating van regsverteenwoordiging oorweeg het nie. Die hof is van mening dat die verhoorliggaam nie regtens verplig is om regsverteenwoordiging toe te laat nie of om selfs die toelating daarvan te oorweeg nie. ${ }^{22}$ Dit is egter duidelik uit die trant van die obiter-opmerkings dat die hof poog om die verhoorliggaam aan te moedig om wel die toelating van regsverteenwoordiging te oorweeg. $\mathrm{Op}$ grond van die obiter-aanmerkings maak die hof ook geen kostebevel nie. Die essensie van die uitspraak is dus dat regsverteenwoordiging slegs ' $n$ reg is indien dit in 'n magtigende bepaling gemagtig word. 'n Outeur van 'n administratiewe handeling mag wel oorweeg om regsverteenwoordiging toe te laat, maar die hof bevind nie dat dit 'n diskresie is wat regtens, dus in alle gevalle met behoorlike aandagbesteding, uitgeoefen moet word nie.

In Moeca v Addisionele Kommissaris, Bloemfontein ${ }^{23}$ het die hersieningshof beslis dat die respondent korrek gehandel het deur regsverteenwoordiging toe te laat tydens 'n ondersoek wat ingrypende gevolge vir die applikant kon hê. Die hof bevind egter dat die regsverteenwoordiger tot so 'n mate gekortwiek is tydens die ondersoek dat die applikant se saak nie behoorlik gestel kon word nie. Die besluit word tersyde gestel en die hof neem ook hierdie optrede teenoor die regverteenwoordiger in ag by die toekenning van 'n kostebevel de bonis propriis teen die respondent. ${ }^{24}$ Hoewel die kernvraag nie die toelating al dan nie van die regsverteenwoordiger was nie, keur die hof die toelating daarvan goed weens die erns van die saak. Die afleiding is dat die aanhoringskomponent van die audi-reël in casu nie nagekom is nie en hierdie uitspraak bied dus indirek steun vir Wiechers en Baxter se standpunt.

21 Supra 526.

22 Supra 526.

23 Moeca v Addisionele Kommissaris, Bloemfontein 19812 SA 357 (O).

24 Supra 366-367. 
Morali v President of the Industrial Court ${ }^{25}$ volg die benadering deur Wiechers en Baxter voorgestel. Die vraag was of die Nywerheidshof 'n diskresie gehad het om toelating van regsverteenwoordiging te oorweeg indien 'n teenparty aangedui het dat dit nie toestemming daartoe verleen nie. Ingevolge die destydse geldende wetgewing het partye die reg gehad op regsverteenwoordiging tydens verrigtinge voor die Nywerheidshof, indien alle partye daartoe toestem. ${ }^{26}$ Die hof bevind dat die gemeenregtelike reg op 'n billike geleentheid om 'n saak te stel, deel vorm van die audi alteram partem-reël. Die hof stel in dieselfde asem dat hoewel daar geen absolute reg op (regs)verteenwoordiging voor administratiewe tribunale bestaan nie, 'n tribunaal wel oor die diskresie beskik om regsverteenwoordiging toe te laat, ingeval die dispuut kompleks is of indien 'n ingewikkelde regsgeskil voor hande is - elke geval moet op meriete beoordeel word. ${ }^{27}$ Die afleiding is dus dat die hof die diskresie om te oorweeg of regsverteenwoordiging toegelaat moet word, beskou as 'n aspek van prosedurele billikheid. Die hof interpreteer die bepaling wat handel oor toestemming vir regsverteenwoordiging ruim. Die bevinding is dat die bepaling die Nywerheidshof se diskresie om toelating van regsverteenwoordiging te oorweeg, uitsluit indien alle partye toestem tot regsverteenwoordiging. Sou toestemming ontbreek, het 'n party nie 'n absolute reg op regsverteenwoordiging nie, maar beskik die Nywerheidshof steeds oor die diskresie om te oorweeg of regsverteenwoordiging toegelaat behoort te word. ${ }^{28}$ Die hof oorweeg onder meer dat die wetgewing daargestel is om, in die woorde van die hof, 'n Dawid sonder slinger teen 'n gewapende en gepanserde Goliat te beskerm. Die hof verwys vervolgens die aangeleentheid terug na die Nywerheidshof om die diskresie omtrent toelating van regsverteenwoordiging uit te oefen. ${ }^{29} 30$

Die vraag in Ibayi City Council v Yantolo ${ }^{31}$ was of regulasies wat bepaal het dat 'n werknemer tydens 'n dissiplinêre verhoor deur 'n "verteenwoordiger" verteenwoordig mag word, slegs voorsiening maak vir leke-verteenwoordiging en dus regsverteenwoordiging uitsluit. ${ }^{32} \mathrm{Na}$

25 Morali v President of the Industrial Court 19871 SA 130 (K).

26 Supra 131-132. Ondanks die naam, het die Nywerheidshof as administratiewe tribunaal gefunksioneer 133.

27 Supra 133.

28 Supra 133-134.

29 Supra 134.

30 Die korrektheid van hierdie uitspraak is later bevraagteken deur die Nywerheidshof in Mynwerkersunie v African Products (Edms) Bpk 19878 ILJ 401 (NH). Die Nywerheidshof bevind dat daar gemeenregtelik geen reg op regsverteenwoordiging voor 'n tribunaal bestaan nie. Dit is van mening dat selfs indien die regsvraag in Morali korrek beslis is, die omstandighede nie sodanig was dat regsverteenwoordiging vereis was nie. Sien Louw 1988 Codicillus 69. Daar moet in gedagte gehou word dat die Nywerheidshof gebonde was aan die beslissing in Morali en nie by magte was om dit omver te werp nie.

31 Ibayi City Council v Yantolo 19913 SA 665 (OK).

32 Supra 667-668. 
ontleding van regspraak en outeursopinies, kom die hof tot die gevolgtrekking dat geen reg op regsverteenwoordiging bestaan in die afwesigheid van 'n statutêre bepaling nie, maar dat daar 'n uitsondering op hierdie reël mag voorkom indien die aangeleentheid gekompliseerd is, waar ontsegging van verteenwoordiging van een of ander aard mag lei tot onbillikheid, deurdat die persoon nie behoorlik geleentheid gebied is om sy saak te stel nie. Die tweede gevolgtrekking is dat waar daar wel voorsiening gemaak word vir verteenwoordiging, die vorm daarvan in die magtigende bepaling self beperk kan word. Die hof bevind egter dat geen sodanige beperking in die onderhawige geval bestaan nie, dat dit nie gevestigde praktyk in arbeidsaangeleenthede is dat voorsiening vir "verteenwoordiging", noodwendig regsverteenwoordiging uitsluit nie en dat geen regsreël volgens die hof bestaan, wat so 'n beperkende interpretasie noop nie. 'n Dissiplinêre tribunaal mag nie self die wye gelding van 'n bepaling soos hierdie beperk nie. ${ }^{33}$

In Dladla $v$ Administrator Natal ${ }^{34}$ was die rede wat aangevoer is vir weiering om regsverteenwoordiging tydens dissiplinêre verrigtinge toe te laat, die bestaande praktyk van die owerheid. Die hof bevind dat die gemeenregtelike reëls van natuurlike geregtigheid geld omdat die huidige geval nie statutêr gereël word nie. Die hof noem pertinent dat dit nie oorweeg of die audi-reël 'n reg op regsverteenwoordiging sou insluit nie. Die saak word benader uit die invalshoek van 'n diskresie wat nie behoorlik uitgeoefen is nie. ${ }^{35}$ Die hof aanvaar dat in gevalle waar 'n statuut nie regsverteenwoordiging verbied of magtig nie, 'n diskresionêre besluit omtrent die aangeleentheid geneem moet word. ${ }^{36}$ Dit is nie duidelik of die hof hierdie bevinding baseer op die onreg wat moontlik mag geskied indien regsverteenwoordiging geweier word, of die aanhaling uit die Morali-saak wat daarop mag dui dat regsverteenwoordiging selfs 'n vereiste vir 'n billike proses mag wees nie. Die bevinding is wel dat die bestaande diskresie in hierdie geval nie behoorlik uitgeoefen is nie, omdat die praktyk van weiering slaafs nagevolg is en die kwessie nie behoorlik oorweeg is nie. ${ }^{37}$ Die hof beslis egter nie of die versuim om die diskresie uit te oefen, neerkom op skending van die regte met betrekking tot prosedurele billikheid nie.

Ten spyte van die howe se huiwering om regsverteenwoordiging as moontlike komponent van die aanhoringsvereiste te erken, dui latere gesag wel daarop dat 'n diskresie erken is indien die magtigende statuut nie die kwessie van regsverteenwoordiging aangespreek het nie - hierdie diskresie moes dan behoorlik, met inagneming van die feite in die aangeleentheid, uitgeoefen

Supra 673-674.

Dladla v Administrator Natal 19953 SA $769(\mathrm{~N})$.

Supra $774-775$.

Supra 776.

Supra 777. 
word. Dit is nie duidelik of behoorlike uitoefening van hierdie diskresie as deel van die vereistes vir prosedurele billikheid, of as substantiewe geldigheidsvereiste vir die optrede, geklassifiseer is nie. Die moontlikheid van regverteenwoordiging op staatsonkoste, is nie geopper nie.

\section{$3 \quad$ Grondwetlike bepalings aangaande regsverteenwoordiging}

Die reg om 'n regsverteenwoordiger te kies, met daardie persoon te konsulteer en verteenwoordig te word, kom aangehoude en beskuldigde persone tydens normale strafregtelike verrigtinge toe in terme van artikels 35(2)(b) en 35(3)(f) van die Grondwet. Indien dit andersins tot wesenlike onreg sou lei, het aangehoudenes en beskuldigdes ook die reg op regsverteenwoordiging op staatsonkoste ingevolge artikels 35(2)(c) en 35(3)(g). Artikels 37(6)(d) en (g) bepaal dat persone wat sonder verhoor aangehou word tydens 'n noodtoestand, ook geregtig is om 'n regsverteenwoordiger te kies, deur daardie persoon besoek te word en om tydens verrigtinge waartydens voortgesette aanhouding oorweeg word, deur die regsverteenwoordiger verteenwoordig te word.

In Park-Ross v Director: Office for Serious Economic Offences ${ }^{38}$ was die hof se uitgangspunt dat die ooreenstemmende regte in die Oorgangsgrondwet ${ }^{39}$ tot die strafproses beperk moes word. Die hof het daarop gewys dat die opstellers van die Grondwet sekere regte pertinent toegesê het aan aangehoudenes en beskuldigdes en dat enige meer uitgebreide toepassing daarvan uitdruklik so geformuleer sou word.

Die enigste ander bepaling in die Handves wat verwys na regsverteenwoordiging is artikel 28(1)(h), wat bepaal dat persone onder 18 die reg het om in siviele verrigtinge wat hul belange raak, op staatsonkoste deur 'n regsverteenwoordiger bygestaan te word, indien dit andersins tot wesenlike onreg sou lei. Laasgenoemde reg sal uiteraard tydens hersieningsverrigtinge geld, maar die administratiewe proses (dus voor aanvang van die geregtelike hersieningsproses) val duidelik nie binne die begrip "siviele verrigtinge" nie.

Geen algemene reg op regsverteenwoordiging tydens administratiewe verrigtinge is dus verskans nie, hoewel sommige administratiewe besluite ook die regte van individue of groepe ernstig mag aantas en die gevolge van administratiewe handelinge drasties en verreikend mag wees. Die vraag het wel ontstaan of die reg op 'n billike proses, vervat in artikel 33, nie die reg

38 Park-Ross v Director: Office for Serious Economic Offences 19952 SA 148 (K) 163.

39 Grondwet van die Republiek van Suid-Afrika 200 van 1993. Verwysing hierna: Oorgangsgrondwet. 
op regsverteenwoordiging sou insluit nie. 'n Benadering wat wel kon lei tot erkenning van sodanige reg, is gesteun deur uitsprake soos die in Van Huyssteen $v$ Minister of Environmental Affairs and Tourism ${ }^{40}$ waarin bevind is dat die reg op 'n prosedureel billike proses nie 'n blote kodifikasie van die gemenereg is nie, maar dat die begrip ruim geïnterpreteer moet word om gevolg te gee aan 'n persoon se fundamentele regte. ${ }^{41}$ Hierdie vraag is egter nie pertinent beslis voor inwerkingtreding van die Wet nie. Aangesien die Wet gepromulgeer is om inhoud te gee aan die bepalings van artikel 33 van die Grondwet, moet dit in samehang daarmee gelees word.

\section{Die Promotion of Administrative Justice Act}

Ondanks spekulasie en selfs voorstelle dat die reg op regsverteenwoordiging deel vorm van die vereistes vir 'n geldige administratiewe proses, het die wetgewer nie daardie weg gevolg nie. Die voorstel deur Nadasen en Shave om regsverteenwoordiging as algemene standaard toe te laat, maar die teenparty geleentheid te bied om daarteen beswaar te maak en dan die aangeleentheid aan die diskresie van die administratiewe orgaan te laat, sou byvoorbeeld ook gevolg kon gee aan die grondwetlike reg. ${ }^{42}$

Die Wet het oor die algemeen nie die gemenereg ten opsigte van die aanhoringsvereiste noemenswaardig uitgebrei, in soverre dit individue wat geraak word deur administratiewe optrede betref nie. ${ }^{43}$ Die uitgangspunt dat 'n billike prosedure afhang van die omstandighede van 'n betrokke aangeleentheid, word bevestig. ${ }^{44}$ Hoewel sekere prosedures voorgeskryf word, ${ }^{45}$ word die feit dat daar ook ingevolge dieselfde artikel afgewyk kan word daarvan, gekritiseer. Outeurs is dit eens dat die sogenaamde "verpligte" prosedures glad nie streng verplig is nie, gesien in die lig van die moontlikheid van afwyking daarvan. ${ }^{46}$ Die slotsom is

40 Van Huyssteen v Minister of Environmental Affairs and Tourism 19961 SA 283 (K).

41 Supra 304A, 305.

42 Nadasen en Shave 1996 Stell LR 358. Die voorstel handel uitsluitlik met verrigtinge voor dissiplinêre tribunale en die outeurs tref nie 'n onderskeid tussen openbare- of staatsorgane en privaatinstellings nie.

43 A 3 van die Wet handel oor prosedureel billike administratiewe optrede wat enige persoon affekteer, teenoor a 4 wat handel met administratiewe optrede wat die publiek affekteer. Die debat rondom die gelding van a 3 en die teenstrydigheid tussen die formulering in a 3 en die definisie van administratiewe optrede in a 1, word nie hier verder gevoer nie. Sien hieroor Burns Administrative Law 213, Currie en Klaaren Benchbook 92-94 en Hoexter en Lyster Administrative Law 236.

44 A 3(2)(a).

45 Ingevolge a 3(2)(b) behels die "verpligte" prosedures: voldoende kennis van die aard en doel van die voorgenome administratiewe optrede; redelike geleentheid om vertoë te rig of insette te lewer; duidelike mededeling wat die administratiewe optrede behels; voldoende kennis van enige reg op interne appèl (indien die moontlikheid bestaan), voldoende kennis van die reg op hersiening, asook voldoende kennis van die reg op redes soos in die Wet uiteengesit.

46 Burns Administrative Law 212, Currie en Klaaren Benchbook 95, Hoexter en Lyster Administrative Law 237-238. A 3(4) bepaal dat daar afgewyk kan word van a 3(2) indien dit redelik en regverdigbaar in die omstandighede is, met verwysing na die oogmerke van die magtigende bepaling; die aard, doel 
onvermydelik dat die billikheid van 'n prosedure kasuïsties bepaal sal word, met klem op die omstandighede van die saak. Die moontlikheid van afwyking is egter beperk tot die "verpligte" prosedures in artikel 3(2) - die diskresies wat verleen word aan 'n administrateur in artikel 3(3) word nie geaffekteer deur die afwykingsbepalings vervat in artikel 3(4) of 3(5) nie.

Ingevolge artikel 3(3)(a) beskik 'n administrateur oor die diskresie om 'n persoon toe te laat om verteenwoordiging te bekom en in ernstige of gekompliseerde gevalle, regsverteenwoordiging te geniet. ${ }^{47}$

Verkeie outeurs noem regsverteenwoordiging een van die nie-kern (non-core) elemente van prosedurele billikheid wat minstens oorweeg moet word voordat die administratiewe handeling verrig word. ${ }^{48}$ Die administrateur moet die nie-kern element oorweeg, maar is uiteraard nie verplig om gevolg te gee daaraan en dus regsverteenwoordiging in alle gevalle toe te laat nie. ${ }^{49}$ Die uitoefening van die diskresie moet egter regmatig en redelik wees en kan op hersiening tersyde gestel word indien dit byvoorbeeld mala fide of onredelik uitgeoefen is of indien irrelevante oorwegings in aanmerking geneem is. ${ }^{50}$ Currie en Klaaren is van mening dat onbehoorlike uitoefening van die diskresie nie neerkom op skending van die reg op prosedurele billikheid nie: sodra die diskresie wel uitgeoefen is, is die vereistes vir prosedurele billikheid nagekom en word dan bepaal of die diskresie behoorlik uitgeoefen is. ${ }^{51}$ Die teenkant is dan dat die vereistes vir prosedurele billikheid nie nagekom is nie, in geval van 'n versuim om die diskresie hoegenaamd uit te oefen. Dit sal die geval wees indien daar 'n gebrek aan aandagsbesteding was en dus geen oorweging van tersaaklike faktore plaasgevind het nie.

Die definisie van administratiewe optrede tref geen onderskeid tussen verskillende tipes administratiewe verrigtinge nie. Artikel 3 bevat eweneens geen sodanige onderskeid nie. Die gevolgtrekking is dus dat die bepaling rakende regsverteenwoordiging geld ten aansien van alle administratiewe optrede wat voldoen aan die vereistes gestel in die definisie - dit is dus nie

van en behoefte aan die administratiewe optrede; die waarskynlike effek van die administratiewe optrede; die dringendheid van die aangeleentheid of die dringendheid van die optrede en die behoefte aan bevordering van effektiewe administrasie en goeie regering. A 3(5) magtig 'n administrateur om af te wyk van a 3(2) deur 'n ander, maar steeds billike, prosedure te volg wat vervat is in 'n magtigende bepaling.

47 A 3(3)(b) en (c) verleen ook die diskresie om 'n persoon toe te laat om inligting en argumente voor te lê of te betwis en om in persoon te verskyn.

48 De Waal, Currie en Erasmus Bill of Rights 512; Currie en Klaaren Benchbook 96.

49 Currie en Klaaren Benchbook 96.

50 De Waal, Currie en Erasmus Bill of Rights 512, Currie en Klaaren Benchbook 96.

51 Currie en Klaaren Benchbook 96. 
beperk tot verrigtinge voor 'n tribunaal wat tipiese kenmerke van die vroeëre regsprekende administratiewe handeling vertoon nie. ${ }^{52}$

Burns se standpunt is dat 'n feite-ondersoek nie regsverteenwoordiging noop nie, maar 'n hoogs tegniese aangeleentheid wat die individue se status, lewenswyse of reputasie mag affekteer, wel regverteenwoordiging mag vereis. Volgens haar is die kernvraag of die persoon die implikasies van die administratiewe optrede na behore verstaan en 'n behoorlike geleentheid gegun is om sy of haar saak te stel. ${ }^{53}$ Devenish, Govender en Hulme is van mening dat regsverteenwoordiging tydens dissiplinêre verhore essensieel is vir die aanbieding van 'n saak. $^{54}$

Dit is belangrik om daarop te let dat die formulering in die Wet nie vereis dat die aangeleentheid ernstig en gekompliseerd hoef te wees ten einde regsverteenwoordiging te vereis nie - voldoening aan slegs een van hierdie voorwaardes behoort reeds die administrateur te oortuig om regsverteenwoordiging toe te laat. Selfs 'n ingewikkelde feitegeskil mag dus aanleiding gee tot toelating van regsverteenwoordiging, terwyl regsverteenwoordiging geldig geweier mag word tydens 'n dissiplinêre verhoor wat nie potensieel ernstige gevolge vir die betrokkene inhou nie en wat ongekompliseerd is.

Hoewel die Hamata-beslissing, waarvan 'n bespreking volg, gelewer is op grond van die geldende reg voor inwerkingtreding van die Wet, bied dit tog riglyne by oorweging van toelating van regsverteenwoordiging en die interpretasie van die regsverteenwoordigingsbepaling in die Wet.

\section{$5 \quad$ Private, huishoudelike tribunale}

Handelinge verrig deur nie-staatsorgane wat nie openbare bevoegdhede uitoefen of openbare funksies verrig ingevolge enige magtigende bepaling nie, is nie administratiewe optrede soos gedefinieer in die Wet nie. ${ }^{55}$ Die bepalings van die Wet is dus nie van toepassing op verrigtinge voor huishoudelike tribunale nie. Die regsposisie ten aansien van hierdie tribunale word egter volledigheidshalwe ook bespreek.

Die howe se uitgangspunt is dat die terme van die ooreenkoms tussen die lid en die vereniging of liggaam, bepalend is wat vereistes vir prosedurele billikheid betref.

52 Vergelyk bv die standpunt van Rose Innes, vn 8 supra.

53 Burns Administrative Law 217.

54 Devenish, Govender en Hulme Administrative Law and Justice 285.

55 Ooreenkomstig die definisie van administratiewe optrede in a 1 van die Wet. 
Die voormalige Appèlafdeling het in 1994 die regsposisie in konteks van 'n dissiplinêre verhoor binne 'n diensverhouding oorweeg in Lamprecht $v$ McNeillie. ${ }^{56}$ Die hof het dit van meet af duidelik gemaak dat die administratiefreg nie toepassing vind nie, aangesien die verhouding tussen die partye geen publiekregtelike element bevat het nie. ${ }^{57}$ Aangesien die verhouding ook nie gebaseer is op die konstitusie van 'n vrywillige vereniging nie, moes die werknemer in die eerste plek bewys dat die dienskontrak uitdruklik of geïmpliseerd die reëls van natuurlike geregtigheid geïnkorporeer het. Die hof steun op die vroeëre uitsprake in Gründlingh v Beyers ${ }^{58}$ en Turner $v$ Jockey Club of South Africa ${ }^{59}$ waarin bevind is dat geen vermoede ten aansien van die gelding van die audi-reël geld in kontraktuele verhoudings nie inkorporasie van die beginsel moes uitdruklik of implisiet wees. ${ }^{60}$

Ten einde te slaag, moes die werknemer ook bewys dat die dienskontrak aan hom 'n reg op regsverteenwoordiging verleen. ${ }^{61}$ Ten spyte van die bestaan van riglyne vir die hantering van dissiplinêre aangeleenthede, bevind die hof dat die werknemer nie daarin kon slaag om te bewys dat die partye die bedoeling gehad het om kontraktueel daaraan gebonde te wees nie. ${ }^{62}$ Die hof bevind wel dat die riglyne daargestel is om te voldoen aan die vereistes van nuwe arbeidswetgewing - die vraag ontstaan dus of hierdie riglyne nie 'n regsbasis vir gelding, dus onafhanklik van die kontrak, gehad het nie. Die hof gaan egter nie op hierdie vraag in nie. Die hof $a$ quo het bevind dat die prosedure ingevolge die riglyne aanhangig gemaak is en dat die werkgewer dus daaraan gebonde was. Hierdie benadering word egter op appèl verwerp. Die hof steun op die skrywe aan die werkgewer, waarin hy kennis van die voorgenome optrede kry en waarin hy ingelig word dat hy geregtig is op verteenwoordiging deur iemand van sy werksplek. ${ }^{63}$ Die hof bevind verder dat daar geen feitebasis bestaan waarop die werkgewer 'n geregverdigde verwagting kon baseer dat verteenwoordiging ingevolge die riglyne toegelaat sou word nie. ${ }^{64}$ Die hof onderskei die onderhawige geval van dié in die Ibayi City Council-

56 Lamprecht $v$ McNeillie 19943 SA 665 (A). Die werknemer het betoog dat twee van sy regte geskend is: die reg op verdere en beter nadere besonderhede tot die klag en die reg op regsverteenwoordig te word tydens die dissiplinêre verrigtinge - 667. Daar word slegs gefokus op die uitspraak ten aansien van laasgenoemde betoog.

57 Supra 668.

58 Gründlingh v Beyers 19672 SA 131 (W) 141.

59 Turner v Jockey Club of South Africa 19743 SA 633 (A) 645-646.

60 Lamprecht $v$ McNeillie supra 668.

61 Ibid.

62 Supra 670.

63 Ibid.

64 Supra 671. Die hof bevind op 671 dat die volgende daarop dui dat regsverteenwoordiging nie by die begrip "verteenwoordiging" ingelees kan word, soos dit in die dissiplinêre riglyne gebruik is nie: die grieweprosedure makk uitdruklik nie voorsiening vir regsverteenwoordiging nie; verteenwoordiging word toegelaat tydens alle dissiplinêre verrigtinge, ondanks die erns van die aantyging en alle ander 
saak, wat betref die konteks en feite. Hoewel die Appèlhof van mening is dat dit nie die korrektheid van die beslissing in Ibayi City Council hoef te oorweeg nie, wys dit wel daarop dat die beslissing klaarblyklik steun op Engelse gesag wat later omver gewerp is. ${ }^{65}$ Die hof verwerp ook die argument dat die werkgewer 'n diskresie gehad het om toelating van regsverteenwoordiging te oorweeg, aangesien die hof bevind dat geen kontraktuele- of regsbasis vir sodanige diskresie bestaan nie. ${ }^{66}$

In Cuppan v Cape Display Supply Chain Services ${ }^{67}$ was die vraag of die applikant 'n reg op regsverteenwoordiging tydens dissiplinêre verrigtinge geniet. Die maatskappy se dissiplinêre prosedure, wat slegs voorsiening gemaak het vir verteenwoordiging deur 'n vakbondwerksvloerverteenwoordiger, is deur verwysing by die diensooreenkoms geïnkorporeer. Die hof bevind (sonder verwysing na enige gesag) dat die Oorgangsgrondwet slegs prosedurele regte verleen aan persone tydens die strafregtelike vervolgingsproses en dat die regte vervat in artikel 25(3) nie geld tydens verrigtinge voor 'n private, huishoudelike tribunaal nie. ${ }^{68}$ Die verwysing na die reëls van natuurlike geregtigheid in die dissiplinêre prosedure, verleen ook nie 'n reg op regsverteenwoordiging nie. Daar kan slegs sprake wees van 'n reg op regsverteenwoordiging indien dit uitdruklik kontraktueel verleen is, of indien daar in uitsonderingsgevalle weens die gekompliseerde aard van die verrigtinge, nie voldoen sal word aan die aanhoringsvereiste tensy regsverteenwoordiging toegelaat word nie. ${ }^{69}$ Die hof bevind egter dat die onderhawige ondersoek eenvoudig is en nie binne die uitsondering val nie. Die hof onderskei die feite van dié in die Ibayi City Council-saak, ${ }^{70}$ deurdat die dissiplinêre kode van die respondent nie 'n algemene reg op verteenwoordiging toelaat nie. Geen afleiding omtrent meer omvangryke regte op verteenwoordiging as dié deur die werksvloerverteenwoordiger, kan uit die kode afgelei word nie. ${ }^{71}$

betrokkenes by die ondersoek is nie regsgeleerdes nie - die doel was dus dat die ondersoek "informeel" sou wees. Met respek kan daar van die hof se benadering verskil word wat minstens een punt betref: dissiplinêre- en grieweprosedures, hoewel gereeld selfs in een dokument vervat, verskil wesenlik wat die aard en gevolge betref.

65 Supra 671-672. Die gesag waarna die hof verwys, is Lord Denning MR se uitspraak in die eerste Pettsaak, ten opsigte waarvan kort daarna bevind is dat dit nie die regsposisie korrek weergegee het nie.

66 Supra 672. Die hof bevind dat die obiter-opmerkings in die Engelse Enderby-saak, nie die SuidAfrikaanse regsposisie weergee nie.

67 Cuppan v Cape Display Supply Chain Services 19954 SA 175 (D).

68 Supra 179.

69 Supra 182.

70 Bespreking onder punt 2 supra.

71 Cuppan v Cape Display Supply Chain Services supra 182 - 183. 
In Cronjé v United Cricket Board of South Africa is selfs 'n meer uitgesproke benadering gevolg. Die hof stel dit duidelik dat die basis van die regsverhouding tussen die partye kontraktueel is, dat die Krieketraad nie openbare bevoegdhede uitoefen nie, dat die reëls van die privaatreg geld en dat die publiekregtelike reëls van natuurlike geregtigheid nie toepassing vind in hierdie verhouding nie, tensy dit geïnkorporeer is in die ooreenkoms met lede of vervat is in die konstitusie van die liggaam of instelling. ${ }^{72}$

Volgens Barrie het die hof in Cuppan nie tred gehou met die ontwikkeling van die plig om billik op te tree nie. Hiervolgens sal billikheid meer behels as blote aanwending van die reëls van natuurlike geregtigheid en sal substantiewe billikheid ook oorweeg word. ${ }^{73}$ Hy staan duidelik die insluiting van regsverteenwoordiging as element van reëls van natuurlike geregtigheid voor. Die Konstitusionele Hof het egter sedertdien bevind dat selfs nie die proporsionaliteitstoets in die Oorgangsgrondwet substantiewe billikheid as vereiste vir geldige administratiewe optrede daargestel het nie. ${ }^{74}$ Of substantiewe billikheid as toets aangewend sal word in die privaatsfeer, is dus sterk te betwyfel, gesien in die lig van die onwilligheid van die hof in Cronjé om regte te erken waar dit nie 'n uitdruklike kontraktuele basis het nie.

Burns betreur die Cronjé-beslissing weens die beperkte, eng benadering tot toepassing van die reëls van natuurlike geregtigheid. Haar standpunt is dat die beginsels van prosedurele billikheid behoort te geld indien daar sprake is van 'n ongelyke (mags-)verhouding, byvoorbeeld wanneer 'n klublid voor 'n dissiplinêre komitee verskyn. ${ }^{75}$

Marais $v$ Democratic Alliance is beslis op die basis dat die Wet nie van toepassing is op dissiplinêre verrigtinge voor interne strukture van 'n politieke party nie. ${ }^{76}$ Die dispuut het nie gehandel oor regsverteenwoordiging nie, maar die relevansie van die uitspraak is geleë in die feit dat die hof ondanks die bevinding dat die optrede nie administratief is nie, wel verwys na die bepalings van die Grondwet omtrent administratiewe geregtigheid, noem dat dit die reëls van natuurlike geregtigheid en vereiste van billikheid omvat en dan voortgaan om die gemeenregtelike posisie rakende hierdie vereistes te bespreek. ${ }^{77}$ By implikasie erken die hof dus dat die grondwetlike beginsels ook op die gemenereg toepassing vind, selfs in gevalle waar die optrede nie voldoen aan die definisie van adminstratiewe optrede vervat in die Wet nie. Die

72 Cronjé v United Cricket Board of South Africa 20014 SA 1361 (T) 1375-1376.

73 Barrie 1996 TSAR 393.

74 Bel Porto School Governing Body v Premier, Western Cape 20023 SA 265 (KH) 292 par [88-89].

75 Burns Administrative Law 211.

76 Marais v Democratic Alliance 20022 BCLR 171 (K) 184 -187 par [48-58].

77 Supra 189-191 par [67-70]. 
verrigtinge voor die huishoudelike tribunaal word dus ook gemeet aan die meer soepel billikheidsvereiste en nie slegs die grondwet van die politieke party nie.

Die benaderings van die onderskeie afdelings van die Hooggeregshof verskil dus ietwat deurdat die plaaslike afdeling geleë te Durban en Pretoria sterk op die kontraktuele basis van die verhouding tussen die partye steun. Die Kaapse benadering steun breedweg die standpunt van Burns en Barrie dat billikheid in alle gevalle oorweeg moet word.

Uitsprake omtrent regsverteenwoordiging voor huishoudelike tribunale handel normaalweg oor dissiplinêre verrigtinge - die onderskeid is egter dat daar in sommige gevalle sprake is van 'n diensverhouding terwyl die verhouding in ander gevalle bestaan tussen 'n organisasie en 'n lid wat nie 'n werknemer is nie en vrywillig aan die organisasie behoort. Tot dusver is daar nie pertinent 'n onderskeid getref tussen die regsposisie van partye in hierdie twee gevalle nie.

Die beslissing van die Hoogste Hof van Appèl in Hamata, waarvan 'n bespreking volg, is ook relevant vir die regsposisie van persone wat voor 'n huishoudelike dissiplinêre tribunaal verskyn.

\section{Hamata $v$ Chairperson, Peninsula Technikon Internal Disciplinary Committee ${ }^{78}$}

\subsection{Feite $^{79}$}

Die eerste appellant, 'n joernalistiekstudent aan die Peninsula Technikon (Pentech), was medeouteur van 'n koerantartikel waarin beweer is dat prostitusie op tersiêre inrigtings se kampusse gedy, dat prostitusie algemeen voorkom op die Pentech-kampus en daar is geïmpliseer dat dit geduld word deur die bestuur. Hy is dissiplinêr daarvan aangekla dat hy homself onder meer skuldig gemaak het aan gedrag wat die Technikon gediskrediteer het. Tydens die dissiplinêre verhoor het die appellant versoek dat hy toegelaat word om deur sy prokureur verteenwoordig te word. Hierdie versoek is geweier deur die interne dissiplinêre komitee (IDK) op grond van die volgende bepaling in die Technikon se reëls:

The student may conduct his/her own defence or may be assisted by any student or a member of staff of the Technikon. Such representative shall voluntarily accept the task of representing the student. If the student is not present, the committee may nonetheless hear the case, make a finding and impose punishment.

78 Hamata $v$ Chairperson, Peninsula Technikon Internal Disciplinary Committee 20025 SA 449 (HHA).

79 Die feite soos uiteengesit in die uitspraak a quo (Hamata v Chairperson, Peninsula Technikon Internal Disciplinary Committee 20004 SA 621 (K) 626-629 par 1-18) en op appèl (supra 454-455 par 1-3), word kortliks weergegee. 
Die IDK het bevind dat die appellant slegs die reg het om deur 'n mede-student of 'n lid van die personeel verteenwoordig te word tydens die dissiplinêre verhoor. Hierna het die appellant homself onttrek van die verrigtinge en die verhoor is in sy afwesigheid voortgesit. Die appellant is skuldig bevind aan die beweerde oortredings en geskors.

Die appellant se interne appèl na die Technikonraad se dissiplinêre komitee (RDK) is van die hand gewys en hy het daarna na die Raad self geappelleer. Die Raad het die aangeleentheid terugverwys na die RDK. Die appellant en sy prokureur was teenwoordig by die aanvang van hierdie vergadering, maar die appellant is weereens regsverteenwoordiging ontsê op grond van die aangehaalde reël en het weereens onttrek van die verrigtinge. Die appellant se appèl is heroorweeg en weer van die hand gewys. Die appellant het weer geappelleer na die Raad, maar hierdie keer sonder sukses.

Die verrigtinge voor die IDK en daaropvolgende mislukte interne appelle is op hersiening geneem in die Kaapse Hooggeregshof. Daar is vervolgens geappelleer teen die uitspraak van die Kaapse Hooggeregshof.

\subsection{Beslissing a quo}

Die gebeure het plaasgevind voor inwerkingtreding van die Wet - die oorgangsbepaling met betrekking tot artikel 33 van die Grondwet het dus nog gegeld. Beide partye het aanvaar dat die administratiefreg van toepassing is en dat die hersiening van administratiewe optrede 'n grondwetlike aangeleentheid is. Die hersieningsgronde is geformuleer in ooreenstemming met die oorgangsbepalings. ${ }^{80}$

Die applikante versoek onder meer 'n verklarende bevel met die strekking dat 'n behoorlike interpretasie van die Pentech-reëls inhou dat studente geregtig is op regsverteenwoordiging voor die IDK en RDK, alternatiewelik dat die Pentech se verteenwoordigingsreël ongrondwetlik is. Gevolglik word dan versoek dat die verrigtinge voor die IDK en RDK tersyde gestel word weens die weiering dat die applikant deur sy prokureur voor hierdie tribunale

80 A quo 630-631 par 24-26. Die hof handel uitvoerig met die applikant se argumente rakende die beweerde miskenning van sy vryheid van spraak en bevind dat die aansoek nie op hierdie grond kan slaag nie (631-635 par 28-41). Die applikant slaag ook nie op grond daarvan dat die dissiplinêre verhoor in camera gehou is nie (639 par 58-61), die beslissing van die interne dissiplinêre komitee onregverdigbaar is met verwysing tot die redes daarvoor verskaf nie (640-641 par 62-64) of dat die interne komitees van die Technikon bevooroordeeld en moontlik beïnvloed was nie (641-644 par 6574). Hierdie aspekte word nie vir doeleindes van hierdie bespreking ontleed nie. 
verteenwoordig word. Die applikant se argument is dat hy 'n reg op regsverteenwoordiging het tydens verrigtinge voor die IDK en RDK. ${ }^{81}$

Die hof staan nie die gevraagde regshulp toe nie. ${ }^{82}$ Die hof se belangrikste bevindings is dat geen algemene reg op regverteenwoordiging buite geregshowe bestaan nie ${ }^{83}$ en dat regsverteenwoordiging nie altyd 'n sine qua non vir 'n billike proses is nie. ${ }^{84}$

Die hof verwerp met reg die applikant se argument dat die regte vervat in artkel 35(3) van die Grondwet as riglyn moet dien wanneer die regte van 'n persoon wat voor 'n administratiewe tribunaal verskyn, bepaal word. Hierdie regte word duidelik slegs aan beskuldigdes verleen en kan nie sonder meer op administratiewe verrigtinge toegepas word nie. ${ }^{85}$

Die hof steun ook op Cuppan $v$ Cape Display Supply Chain Services ${ }^{86}$ waarin die gemeenregtelike posisie bevestig is en verder bevind is dat die regte van 'n persoon in 'n kontraktuele verhouding, bepaal word deur die bedinge van die kontrak. Hoewel die hof dit nie uitdruklik bevind nie, is die implikasie dat die applikant se regte (deels?) bepaal moet word deur sy ooreenkoms met Pentech. Die hof bevind egter bloot dat geen basis vir die gevraagde bevel bestaan nie, sonder om daarop in te gaan of die basis kontraktueel of buite-kontraktueel van aard sou wees.

Die applikant argumenteer dat die omstandighede en kompleksiteit van elke geval sal bepaal of regsverteenwoordiging vereis word vir 'n billike proses. ${ }^{87}$ Die betoog is verder dat regverteenwoordiging in die onderhawige geval, gegewe die erns van die aanklagte, erns van die moontlike strawwe en ingewikkelde grondwetlike beginsels betreffende vryheid van spraak, noodsaaklik was vir 'n billike prosedure en dat dit onbillik is om verteenwoordiging te beperk tot verteenwoordiging deur mede-studente of personeellede van Pentech. ${ }^{88}$ Die hof stem saam met Baxter se siening dat regsverteenwoordiging wel in sekere omstandighede 'n sine qua non vir 'n billike proses mag wees, maar bevind dat dit nie in hierdie geval so is nie omdat nòg die feite nòg die regsbeginsels besonder ingewikkeld is, ten spyte van die moontlike ernstige gevolge wat die dissiplinêre verhoor vir die applikant mag inhou. Die hof sinspeel selfs daarop

81 А quo 635-636 par 44.

82 Supra 639 par 57.

83 Supra 638 par 52.

84 Supra 638 par 56.

85 Supra 636 par 46 en 636-637 par 48. Die hof steun ook op die uitspraak in Park-Ross supra dat hierdie regte tot die strafproses beperk moet word.

86 Cuppan v Cape Display Supply Chain Services 19954 SA 175 (D), verwysing op 638 par 52 van Hamata-beslissing. Verwys na die bespreking onder punt 5 supra.

87 Supra 636 par 45.

88 Supra 638 par 55. 
dat die huidige geval 'n voorbeeld is van die "over-judicialisation" van eenvoudige ondersoeke waarteen Baxter waarsku, sou regsverteenwoordiging voor die voet toegelaat word. ${ }^{89}$

Hoewel die partye dit eens is dat hersiening van administratiewe optrede 'n grondwetlike aangeleentheid is, handel die hof a quo by oorweging van die reg op regsverteenwoordiging uitsluitlik met die gemenereg. Die hof oorweeg nie eens die moontlike invloed van die Grondwet op die (voormalige) regsposisie nie. Die enigste verwysing na die Grondwet is dat die regte vervat in artikel 35(3) nie van toepassing is op administratiewe optrede nie. Die hof onderskei ook nie die onderhawige geval van die posisie in die Cuppan-saak, waar die regsverhouding tussen die partye kontraktueel van aard was nie. Reeds voor hierdie uitspraak was daar voldoende grond om 'n onderskeid te tref tussen regsverhoudings van 'n publiekregtelike aard en dié wat suiwer kontraktueel is. ${ }^{90}$

\subsection{Beslissing op appèl}

Die hof se uitgangspunt is dat die vraag rondom die weiering van die interne dissiplinêre komitee, bepalend sal wees in hierdie aangeleentheid en dat alle ander geskilpunte dan oorbodig sal wees. Die hof bevind dan ook uiteindelik dat die skuldigbevinding en skorsing van die appellant tersyde gestel moet word en dat die aangeleentheid terugverwys moet word vir heroorweging deur die interne dissiplinêre komitee. ${ }^{91}$

Die hof se benadering is dat interpretasie van die Pentech-reël moet geskied met verwysing na bestaande uitlegreëls, maar ook met inagneming van enige tersaaklike waardes vervat in die Handves van Fundamentele Regte. Die hof beklemtoom dat die reg op regsverteenwoordiging beperk is tot gearresteerdes en beskuldigdes, die reg sou uitdruklik verleen gewees het indien dit die oogmerk was om sodanige reg ook in die administratiewe proses te erken. ${ }^{92}$ Ter ondersteuning van hierdie argument verwys die hof na die diskresie wat in die Wet verleen word en ook die feit dat administrateurs met diskresionêre bevoegdhede beklee is om uiting te gee aan die beginsel dat 'n billike proses afhang van die omstandighede van elke geval. Die grondwetlike en statutêre posisie weerspieël die huiwering om regsverteenwoordiging as absolute reg toe te laat, maar erken terselfdertyd dat regsverteenwoordiging in sekere gevalle

89 Supra 638-639 par 56.

90 Verwys na bespreking onder punt 7 infra.

91 Appèluitspraak, vn 55, 454-455 par 1-4; 462 par 25 en 465 par 37. Die beslissing is eenparig deur 'n Volbank gelewer.

92 Supra 456-457 par 8. 
wel 'n vereiste vir 'n billike proses mag wees. ${ }^{93}$ Geen reg op regsverteenwoordiging kan dus afgelei word nie - slegs die diskresie om wel regsverteenwoordiging toe te laat. Hierdie buigbaarheid is 'n grondwetlike imperatief. Die tipe administratiewe orgaan en tipe verrigtinge sal egter bepalend wees vir die vraag met betrekking tot die toelating van regsverteenwoordiging, wat beperk is tot gevalle waar dit noodsaaklik is ten einde 'n billike proses te verseker. ${ }^{94}$

Die hof bevind dat die doel van die verteenwoordigingsreël is om aan te dui dat geen reg op verteenwoordiging deur 'n buitestaander tydens dissiplinêre verrigtinge bestaan nie. Met verwysing na die feite bevind die hof dat die IDK 'n regsentiteit is wat slegs die bevoegdhede mag uitoefen wat daaraan verleen word ingevolge die reëls. Die vertrekpunt is egter dat daar grondwetlik vereis word dat die kwessie rondom regsverteenwoordiging met soepelheid benader word en 'n uitdruklike magtiging vir die uitoefening van hierdie diskresie in die reëls word nie vereis nie. Daar is ook geen aanduiding in die reëls dat die sogenaamde residuele diskresie van die IDK ten opsigte van regsverteenwoordiging, uitgesluit is nie en geen sodanige doel kan afgelei word uit die verteenwoordigingsreël nie. Die IDK beskik dus oor 'n diskresie om regsverteenwoordiging toe te laat indien die omstandighede dit vereis. ${ }^{95}$ Aspekte wat deur die IDK oorweeg moet word, sluit in die aard van die beweerde wangedrag, ingewikkeldheidsgraad van feite- en regsvrae, potensiële erns van die gevolge van 'n skuldigbevinding, beskikbaarheid van toepaslik gekwalifiseerde regsgeleerdes verbonde aan die Pentech as personeel of studente, die feit dat iemand wat opgelei is in die reg optree as aanklaer namens Pentech tydens die verrigtinge, asook enige ander aspek wat relevant mag wees tot die vraag of die student beperk moet word tot die soort verteenwoordiging wat deur die verteenwoordigingsreël toegelaat word. Pentech se geregverdigde behoefte om die verrigtinge "binneshuis" te hou, is een van die faktore wat sodoende oorweeg word, maar dit mag nie die bepalende faktor by uitoefening van die diskresie wees nie. ${ }^{96}$

Die hof noem verder dat dit van oordeel is dat toepassing van die gemeenregtelike reëls tot dieselfde resultaat sou lei, aangesien dit ook vereis het dat dissiplinêre prosedures billik moet wees, hetsy die handeling as administratief getipeer sou word en of 'n staatsorgaan betrokke

93 Ter ondersteuning van eersgenoemde stelling verwys die hof na die uitsprake in Dabner supra, Maynard v Osmond (QB) en Lamprecht v McNeillie supra, maar verwys nie na enige van die gesag bespreek onder punt 2, ter stawing van die tweede stelling nie. Die hof noem slegs dat daar met verloop van tyd toenemend aanvaar is dat regsverteenwoordiging in sommige gevalle 'n vereiste vir ' $n$ billike proses mag wees. Supra 457-458 par 11, 458 vn 14.

94 Supra 457-458 par 9-13.

95 Supra 460-461 par 19-20.

96 Supra 461 par 21. 
was of nie. Die hof verwys nie na gemeenregtelike gesag vir hierdie stelling nie, maar verwys bloot na die stelling in die Bel Porto-uitspraak dat artikel 23(2)(b) in die Oorgangsgrondwet 'n samevatting en in sommige gevalle ook 'n uitbreiding van die gemeenregtelike posisie is. ${ }^{97}$

Tensy sodanige diskresie uitdruklik uitgesluit word, beskik 'n dissiplinêre liggaam oor die diskresie om te oorweeg of regsverteenwoordiging vereis word ten einde billikheid te verseker. Die regsgeldigheid van enige uitsluiting van die diskresie kan ook oorweeg word, maar dit is nie tersake in hierdie saak nie. Die vraag onder welke omstandighede 'n uitsluiting van die diskresie regsgeldig sal wees, word dus pertinent deur die hof oop gelaat. ${ }^{98}$

Die uitoefening van die diskresie is 'n ad hoc besluit wat deur die IDK gemaak moet word en die hof is nie bereid om aan die IDK voor te skryf wat daardie besluit moet wees nie. Omrede die diskresie nog nooit uitgeoefen is nie, verwys die hof die aangeleentheid dus terug vir heroorweging deur die IDK. ${ }^{99}$

\section{$7 \quad$ Gevolgtrekking}

Tydens alle dissiplinêre verrigtinge beskik die dissiplinêre liggaam oor 'n diskresie om te oorweeg of regsverteenwoordiging toegelaat moet word ten einde te voldoen aan die vereiste van prosedurele billikheid. Die praktiese implikasie hiervan is dat dissiplinêre liggame in alle gevalle oor hierdie diskresie beskik, hetsy dit uitdruklik verleen word, geïmpliseer word of glad nie aangespreek word nie. Die hof in Hamata bevind dat die bestaan van hierdie diskresie gegrond is op 'n behoorlike interpretasie van die gemenereg en die Grondwet. Die tipe faktore wat oorweeg moet word by uitoefening van hierdie diskresie, is ook deur die hof uitgespel.

Die vraag of, en indien wel, onder watter omstandighede die diskresie regsgeldig uitgesluit mag word, bly steeds onbeantwoord. In hierdie verband word voorgestel dat daar onderskei moet word tussen gevalle waar die Wet toepassing vind aan die een kant en waar daar sprake is van 'n regsverhouding gebaseer op kontrak, dus tipies verrigtinge voor 'n huishoudelike tribunaal, aan die ander kant.

Dit is interessant dat die Natalse hof in Dladla $v$ Administrator Natal ${ }^{100}$ nie steun op die uitspraak in Lamprecht $v$ McNeillie ${ }^{101}$ nie en hierdeur implisiet die regsposisie van 'n

97 Supra 461-462 par 23.

98 Supra 461-462 par 23.

99 Supra 462 par 25.

100 Verwys na bespreking onder punt 2 supra.

101 Verwys na bespreking onder punt 5 supra. 
verhouding met 'n statutêre komponent onderskei van dié daarsonder. Hierdie benadering is gevolg deur die wetgewer wat duidelik beoog het om nie die Wet van toepassing te maak op optrede van privaat persone en -instansies nie.

Die posisie van 'n persoon wat te staan kom teen die staat in een of ander formaat en die beherende liggaam van 'n organisasie waarvan die lidmaatskap en ondersteuning vrywillig is, is nie identies nie. Aan die een kant word die persoon in die publiekregtelike verhouding gekonfronteer deur die magtige staat wat beklee is met owerheidsgesag. Aan die ander kant kom die individu te staan teen die private liggaam se beheerliggaam wat weliswaar in 'n vorm van 'n magsverhouding teenoor die individu staan, maar wat glad nie met betrekking tot omvang van hulpbronne of omvang van gesag met die staat vergelyk kan word nie. Dit is debatteerbaar of daar 'n onderskeid getref moet word tussen die persoon wat vrywillig die verhouding met die staat betree ${ }^{102}$ en die persoon wat teen wil en dank onderworpe is aan regulasie deur die staat. ${ }^{103}$ Dit is van belang dat die Wet geen onderskeid tref tussen sodanige persone rakende die toewysing van regte nie.

Die regsposisie van 'n persoon wat verskyn voor 'n huishoudelike tribunaal is tans dat die liggaam beskik oor 'n diskresie om regsverteenwoordiging toe te laat, maar dat die diskresie moontlik kontraktueel uitgesluit mag word. Hoewel die hof in Hamata nie die vraag aangespreek het nie, is die submissie dat regsgeldigheid van enige uitsluiting van die diskresie oorweeg sal word met verwysing na relevante omstandighede in die geval, asook die algemene billikheidsvereiste wat die hof in Hamata bevind gemeenregtelik gegeld het. Die hof in Marais was van mening dat dit nou vervat is in artikel 33 van die Grondwet.

Die vraag ontstaan of daar nie 'n duidelike onderskeid getref moet word tussen gevalle waar 'n diensverhouding in die privaatsfeer bestaan en gevalle waar bloot sprake is van vrywillige lidmaatskap nie. In geval van 'n diensverhouding het die wetgewer dit reeds voor die huidige grondwetlike bedeling raadsaam geag om regte en verpligtinge van partye statutêr te reël, onder meer omdat daar 'n behoefte aan beskerming van die regte van die werknemer bestaan. Die posisie van 'n werknemer wat afhanklik is van sy werkgewer vir 'n inkomste, is ook meer benard as die van 'n klublid wat hoogstens lidmaatskap ontsê kan word. Daar kan geredeneer word dat die huidige soepel benadering voorsiening maak vir 'n onderskeid tussen genoemde gevalle aangesien die moontlike erns van die gevolge wel oorweeg sal word. Daar kan egter

102 Deur bv aansoek te doen vir 'n lisensie, vgl Wiechers se benadering onder punt 2 supra.

$103 \mathrm{Bv}$ deur die heffing van eiendomsbelasting. 
ook geredeneer word dat die bepalings van die Wet op Arbeidsverhoudinge ${ }^{104}$ wat handel oor 'n billike dissiplinêre proses, sonder veel moeite gewysig kan word sodat dit soortgelyke beskerming as die Wet bied.

Die posisie in verhoudings met die staat of 'n liggaam wat openbare bevoegdhede of pligte uitoefen, verskil egter.

In strafregtelike vervolgings word die reg op regsverteenwoordiging as noodsaaklik gereken hierdie reg word gebaseer op beide die reg op 'n billike verhoor en die reg op gelykheid voor die reg, soos toegepas in die adversariële proses. ${ }^{105}$ 'n Billike verhoor sal slegs plaasvind indien 'n persoon sy of haar saak op 'n effektiewe wyse sal kan aanbied - in heelwat gevalle beskik persone nie oor daardie vermoë nie en sal regsverteenwoordiging essensieel wees om te voldoen aan hierdie vereiste. Die vereiste van gelykheid voor die reg hou in dat geregtigheid nie alleen dié moet toekom wat oor die finansiële vermoë beskik om regsverteenwoordiging te bekostig nie. ${ }^{106}$

Hierdie uitgangspunte geld uiteraard nie net so in die administratiewe proses nie. Die aanhoringsvereiste en geleentheid om 'n saak te stel, kan as beginsel ontleen word aan die strafproses. Wiechers het immers reeds twintig jaar gelede 'n situasie bepleit waarin in ag geneem word of 'n persoon in staat is om sy of haar saak te stel, met of sonder 'n regsverteenwoordiger. Kennis van die aard en doel van die voorgenome administratiewe optrede, geleentheid om insette te lewer en verpligte mededeling van regte, soos byvoorbeeld die reg om redes te versoek en reg op interne appèl en hersiening, word verwelkom, maar stel die ongesofistikeerde persoon nog nie in staat om die erns en impak van die voorgenome optrede te besef of sy of haar saak behoorlik aan die besluitnemer voor te lê nie. Die huidige soepel benadering tot toelating van regsverteenwoordiging, indien korrek toegepas, behoort juis onreg op hierdie gebied te voorkom. Die basiese vertrekpunt dat prosedurele billikheid met verwysing na die omstandighede van 'n saak bepaal word, behoort oorweging van faktore soos die geaffekteerde persoon se geletterheids- en sofistikasievlak, asook vermoë om die erns en impak van die voorgenome optrede te besef en self sy of haar saak self te stel, in te sluit.

Indien die Wet van toepassing is, met ander woorde indien die handeling voldoen aan alle vereistes gestel in die definisie van administratiewe optrede, behoort die diskresie om toelating

104 Wet op Arbeidsverhoudinge 66 van 1995. Daar word veral verwys na a 188 van gemelde wet en a 4 van Bylae 8 (Goeie Praktykskode: Ontslag), wat handel oor 'n billike prosedure.

105 Bekker 1997 De Iure 216.

106 Ibid. 
van regsverteenwoordiging te oorweeg, ${ }^{107}$ te geld sonder die moontlikheid van uitsluiting. Enige uitsluiting van die diskresie om die toelating van regsverteenwoordiging te oorweeg, behoort dus per se ongeldig te wees, hetsy dit statutêr of kontraktueel (uitdruklik of indirek) ${ }^{108}$ geskied.

Hierdie benadering is in lyn met die oorkoepelende oogmerke van die Wet, soos uiteengesit in die Aanhef. Die Wet self ${ }^{109}$ maak voorsiening daarvoor dat afgewyk kan word van die vereistes gestel in artikel 3(2), maar geen voorsiening word in die Wet gemaak vir uitsluiting van die diskresies vervat in artikel 3(3) nie. Die Hamata-uitspraak is gelewer op grond van die grondwetlike bepalings betreffende prosedurele billikheid. Die Wet was nog nie in werking tydens die gebeure wat voor die hof gedien het nie. Die hof het ook duidelik verwys na die posisie ten opsigte van verrigtinge voor alle tipes dissiplinêre liggame, nie slegs waar daar sprake was van administratiewe optrede nie. Die Wet is gepromulgeer ingevolge die Grondwet en die benadering sal verder strook met die bevinding in Hamata dat soepelheid omtrent die toelating van regsverteenwoordiging 'n grondwetlike imperatief is. Die bestaan van 'n diskresie in gevalle waar administratiewe optrede verrig word, is ook voor die hand liggend nie sinoniem met die summiere toelating van regsverteenwoordiging in aangeleenthede ten opsigte waarvan die erns of kompleksiteit dit nie regverdig nie. Wanneer die besluitnemer egter nie behoorlik oorweging skenk aan die tersaaklike faktore nie of onvoldoende aandag bestee aan die oorweging van die aangeleentheid, sal die weiering van regsverteenwoordiging dus hersienbaar wees omdat die diskresie nie na behore uitgeoefen is nie.

Dit is duidelik dat die Wet wyer gelding geniet as bloot verrigtinge voor dissiplinêre liggame bostaande benadering behoort dus gevolg te word in alle gevalle waar 'n persoon se regte of geregverdigde verwagtinge geaffekteer word deur administratiewe optrede.

Die klem op die omstandighede en meriete van elke saak verseker 'n gebalanseerde benadering. Dit vermy sogenaamde oorjudisialisering en oorbelading van die administrasie en handhaaf in beginsel die onafhanklikheid en integriteit van administratiewe organe. Die soepel benadering bied terselfdertyd wel beskerming van regte waar dit geverg word, bied 'n persoon die billike

107 A 3(3)(a) van die Wet.

$108 \mathrm{Bv}$ deur kontraktueel ooreen te kom dat ' $\mathrm{n}$ kontraksparty gebonde sal wees aan reëls of regulasies van tyd tot tyd uitgevaardig deur die administratiewe orgaan. Sodanige reëls of regulasies kan dan die moontlikheid van regsverteenwoordiging uitsluit.

109 A 3(4) van die Wet. 
geleentheid om sy of haar saak te stel en behoort te verseker dat 'n persoon ook glo dat hy of sy 'n geleentheid gebied word om sy of haar saak behoorlik te stel. ${ }^{110}$

Die uitgangspunt dat materiële welvaart nie deurslaggewend moet wees tot die vraag of geregtigheid geskied in 'n betrokke aangeleentheid nie, is meer problematies. Beperkte finansiële hulpbronne maak dit onmoontlik om tans regshulp op staatsonkoste in alle strafsake te verskaf. Die idee van staatsgesubsieerde regshulp tydens die administratiewe proses blyk dus op die oog af 'n onbereikbare ideaal te wees. Ontwikkeling in die rigting dat dit vereis mag word vir billike optrede in ernstige, gekompliseerde sake, is uiteraard nie uitgesluit nie. Die vraag of die regsplig op die staat om positief op te tree en om gevolg te gee aan die regte vervat in die Handves, ${ }^{111}$ dus ook die reg op 'n billike administratiewe proses, so wyd geïnterpreteer sal word om verskaffing van regsverteenwoordiging op staatsonkoste in verdienstelike gevalle te vereis, moet nog beantwoord word.

110 Verwys na opmerkings deur Nadasen en Shave 1996 Stell LR 357.

111 A 7(2) van die Grondwet. 


\section{Bibliografie}

Barrie 1996 TSAR

Barrie GN "Right to representation in domestic tribunals" 1996 TSAR 390-393

Baxter Administrative Law

Baxter L Administrative Law (Juta Cape Town 1984)

Bekker 1997 De Iure

Bekker PM "The right to legal counsel and the Constitution" 1997 De Iure 213-226

Burns Administrative Law

Burns Y Administrative Law under the 1996 Constitution $2^{\text {nd }}$ ed (Butterworths Durban 2003)

Currie en Klaaren Benchbook

Currie I en Klaaren J The Promotion of Administrative Justice Act Benchbook (SiberInk

Cape Town 2001)

De Waal, Currie en Erasmus Bill of Rights

De Waal J, Currie I en Erasmus G Bill of Rights Handbook (Juta Lansdowne 2001)

Devenish, Govender en Hulme Administrative Law and Justice

Devenish GE, Govender K en Hulme D Administrative Law and Justice in South Africa (Butterworths Durban 2001)

Hoexter en Lyster Administrative Law

Hoexter C en Lyster R "Volume Two: Administrative Law" in Currie I (red) The New Constitutional and Administrative Law (Juta Lansdowne 2002)

Louw 1988 Codicillus

Louw C "Industrial Court - legal representation - Mynwerkersunie $v$ African Products (Edms) Bpk 19878 ILJ 401 (IC)" 1988 Codicillus 69

Nadasen en Shave 1996 Stell LR

Nadasen S en Shave K "Legal representation before disciplinary tribunals: praxis in need of reappraisal?" 1996 Stell LR 351-360 
Rose Innes Judicial Review

Rose Innes LA Judicial Review of Administrative Tribunals in South Africa (Juta Cape Town 1963)

Wiechers Administratiefreg

Wiechers M Administratiefreg (Butterworths Durban 1984 )

\section{Register van hofsake}

Bel Porto School Governing Body v Premier, Western Cape 20023 SA 265 (KH)

Cronjé v United Cricket Board of South Africa 20014 SA 1361 (T)

Cuppan v Cape Display Supply Chain Services 19954 SA 175 (D)

Dabner v SAR \& H 1920 AD 583

Dladla and Others $v$ Administrator Natal and Others 19953 SA 769 (N)

Fraser v Mudge (1975) 3 All ER 78 (CA)

Gründlingh v Beyers and Others 19672 SA 131 (W)

Hamata v Chairperson, Peninsula Technikon Internal Disciplinary Committee 20004 SA 621 $(\mathrm{K})$

Hamata and Another v Chairperson, Peninsula Technikon Internal Disciplinary Committee and Others 20025 SA 449 (HHA)

Ibayi City Council v Yantolo 19913 SA 665 (ECD)

Lamprecht and Another v McNeillie 19943 SA 665 (A)

Marais v Democratic Alliance 20022 BCLR 171 (K)

Maynard v Osmond [1977] 1 QB 241 (CA)

Moeca v Addisionele Kommissaris, Bloemfontein 19812 SA 357 (O)

Morali v President of the Industrial Court and Others 19871 SA 130 (K)

Mynwerkersunie v African Products (Edms) Bpk 19878 ILJ 401 (NH)

Park-Ross and Another v Director: Office for Serious Economic Offences 19952 SA 148 (K)

Smith $v$ Beleggende Outoriteit van Kommandement Noord-Transvaal van die SA Weermag 19803 SA 519 (T)

Turner v Jockey Club of South Africa 19743 SA 633 (A)

Van Huyssteen NO v Minister of Environmental Affairs and Tourism 19961 SA 283 (K)

\section{Register van wetgewing}

Grondwet van die Republiek van Suid-Afrika 200 van 1993 
Grondwet van die Republiek van Suid-Afrika 1996

Promotion of Administrative Justice Act 3 van 2000

Wet op Arbeidsverhoudinge 66 van 1995 